\title{
THE FALL AND RISE OF COVENANT, LAW AND TREATY
}

\author{
Kenneth A. Kitchen
}

The theme of covenant (and especially the Sinai covenant and its renewals) has attracted much debate for over a century in Old Testament studies. In a recent book, succinctly and clearly written and handsomely presented, Professor E. W. Nicholson has reviewed the vicissitudes of covenant in Old Testament studies (in effect) from Wellhausen to the present decade. ${ }^{1}$ The thrust of his book is that Old Testament studies have come full circle: Wellhausen originally denied the covenant (both term and concept) any effective existence until the eighth and particularly the seventh centuries BC, and now (after varied peregrinations) not a few contemporary Old Testament scholars, including Nicholson, wish to return to that position.

As chapter 1 makes clear, Wellhausen's view divided opinions sharply for some forty years (1878-1918). Such scholars as Stade (1887), Meyer (1906) and Gunkel (1913) followed Wellhausen in denying the antiquity of the Sinai covenant. Others such as Kittel (1888), Steuernagel (1899), Procksch (1906) and Gressmann (1913) all argued in varying degree for a covenant enacted in some form at Sinai under Moses. The term berrit for 'covenant' was discussed at length with varying results. Alone, J. Pedersen (1914) invoked non-biblical data, but utilized only the (impossibly late) pre-Islamic Arabian sources, refusing to consider data from ancient Mesopotamia on the inadequate ground that its (supposedly) urban civilisation lent a different significance to the term there. So, by 1920 , no agreed solution had emerged.

${ }^{1}$ This is a review-paper of E. W. Nicholson, God and His People, Covenant and Theology in the Old Testament (Oxford, OUP 1986) intended to further discussion. A much briefer form of this study formed part of a paper delivered at the Old Testament Study Group at Tyndale House in July, 1988. 
But in the ensuing thirty years (1920-50), "The Controversy Ended', to reuse the title of chapter 2. From the mid-twenties, more and more scholars accepted both the antiquity and significance of 'covenant' in early Israel, arguing in its favour under fresh impulses. Such were: Mowinckel (1921-4, 1927, 1951: monarchy period), Hempel (1926), Weiser (1928, 1931, 1948), Galling (1928), especially Eichrodt (1933-9); Gunkel (1930, changing from his 1913 stance); Porteous (1936), H. W. Robinson (1946) and Rowley (1950), G. E. Wright (194452), and Noth (1930-50). The basic reasons were threefold: (1) re-emphasis on Israelite religion having been founded on historical events (not a mythical 'nature-religion'); (2) the fresh emphasis on the role of cult (Mowinckel), leading to the theory of an annual autumn covenant-renewal feast; (3) the thesis of a twelve-tribe league based on a covenant enacted at Shechem (Joshua 24), Noth's 'amphictyony'. As Nicholson indicates, these were not all new points-but new factors led to this shift in opinion: (1) 'the rebirth of interest in Old Testament theology' (p. 34); (2) greater interest in determining what was distinctive in Israelite religion within the NearEastern world; and (3) above all, the impact of the sociology of religion, particularly through Max Weber (1926). The latter saw religion as a basic ingredient of society, belonging to the very "nuts and bolts"' as Nicholson pithily puts it (pp. 37ff.). Here, covenant was a functional kingpin, binding the tribes to each other and to YHWH. Parallel developments in thought affected treatment of the covenants with Abraham (Gen. 15) and David (2 Sam. 23:1-7).

\section{II}

It is since 1950 that extensive non-biblical data have been utilized in further study of covenant. The trail-blazer was G. E. Mendenhall in his famous paper of $1954 .^{2}$ In his third chapter Nicholson reviews with care the views of just three prominent contributors: Mendenhall, McCarthy, and Weinfeld (plus

2'Covenant Forms in Israelite Tradition', BA 17 (1954) 50-76, esp. 53-70; reprinted in pamphlet form, in G. E. Mendenhall, Law and Covenant in Israel and the Ancient Near East (Pittsburg 1955). 
secondarily, contributions on terminological details). These three alone are the practical basis for his assessment and criticism of the use of the ancient Near Eastern treaties for comparison with the Old Testament covenants (pp. 68-82). He (rightly) doubts these scholars' use of treaty-data with Exodus 19 and (for blessings/curses) with Exodus 23:20-33. He further (but less convincingly) proceeds to deny that Deuteronomy is at all 'treaty-like' in its presentation (p. 71). Deuteronomy 28 is a 'crucial' test for the presence of treaty-form in Deuteronomy for Nicholson (p. 73); and he rejects Weinfeld's use of the curses to link Deuteronomy with the first-millennium treaties, dismissing them from relevance, just as McCarthy had attempted to deny the relevance of the earlier (secondmillennium) treaties. He is sceptical of the appeal to terminology-most of it simply reflects ordinary life, not specific covenant/treaty relations. Thus, he concludes that 'the attempt to relate the Old Testament covenant to suzerainty treaties may be said to represent a dead-end in the social/functional approach' -instead, he would prefer to treat 'covenant' as simply a 'theological idea'. Hence his return to the position of Wellhausen, giving only a limited role to the social dimension.

However, the treaties cannot be dismissed quite so neatly as this (cf. IVff. below); but first, a rapid overview of the rest of the book.

\section{III}

The shift of covenant from early institution to late theological construct has found (during the 1960s to 1980s) its leading exponents in L. Perlitt (1969) and E. Kutsch (1973); but they are not alone, cf. Whitley (1963) and Fohrer (1966). Kutsch's insistence that berit means nothing more than 'obligation' is so unrealistic that Nicholson rightly (pp. 104f.) rejects it. Perlitt in essence limits covenant to the seventh century BC onward (cf. Wellhausen), while Nicholson goes back to the eighth century BC. That conclusion emerges from Part II of the book, in which the author gives his view of: Exodus 24:1-2, 9-11; 34:10-28; Joshua 24:1-28; Exodus 19:34-8; 24:3-8; and Hosea 6:7, 8:1. This comprises his chapters 5-9.Part III (chapter 10) gives 
Nicholson's synthesis of Israel's religious history, relating to covenant, based on chapter 3 and Part II. For him, emergence of the covenant-concept in the eighth/seventh centuries BC is: (1) coeval with Wellhausen's postulated 'break' in Israelite religion then from 'natural bond' to a theological 'moral commitment'; and (2) the key to the distinctiveness of Israel's faith over against the surrounding Near Eastern cultures. He admits having two grounds for his stance additional to Wellhausen's: use of much more ancient Near Eastern data as background, and some use of sociological sidelights. Religion he suggests, changed from legitimising a society to putting it ('desacralised') under moral judgement.

\section{IV}

Nicholson's synthesis depends directly on the correctness of his conclusions about covenant and treaty (being unrelated), and on his assumption that both berit and the covenant-concept belong to the eighth/seventh centuries onwards, at least in Israel. Here, in chapter 3, is the 'Achilles heel' of his entire undertaking, in terms of both fact and methodology, failing to take proper account of Near-Eastern data, and only at secondhand.

Let us tackle first a modest factual omission of such importance that it is ultimately fatal to this position on covenant adopted by Wellhausen, Nicholson and others. This concerns the term berit. In assessing such a term in Hebrew/West Semitic, it is essential to consider all the pertinent evidence. Here, that means including the extra-biblical evidence-but at no point does Nicholson even mention this evidence, let alone evaluate it. Neither does he ever mention pertinent studies that do deal with the extra-biblical occurrences of berit. The reasons for this omission are not evident. ${ }^{3}$ That external

\footnotetext{
${ }^{3}$ The author of God and His People virtually never cites studies from any journal outside the biblical or theological fields (other then the well-known JNES and $B A S O R ; Z A$ and $A H D O$ are each cited once). Consequently he overlooks important studies in JAOS (by Weinfeld, thrice over), in Ugarit-Forschungen (by Weinfeld; Kitchen), as well as H. Tadmore "Treaty and Oath in the Ancient Near East', in G. M. Tucker, D. A. Knight (edd.), Humanizing America's Iconic Book (SBL Centennial Addresses 1980; Chico, Scholars Press 1982) 127-52. However, much the same may be said of the work of Kutsch and Perlitt.
} 
evidence consists of West-Semitic brt occurring as a loanword in Egypt in the thirteenth/twelfth centuries BC, in Ugaritic in the thirteenth century $B C$, and in peripheral Akkadian (as a West-Semiticism) in Central Syria c. $1400 \mathrm{BC}$.

The term brt is used in its political sense of (vassal) treaty, possibly also as agreement/covenant, c. $1170 \mathrm{BC}$ (Year 11 of Ramesses III). ${ }^{4}$ Remarkably, the Egyptian scribes use the word in dealing with defeated Libyans; clearly this word borrowed from Canaan had become sufficiently current to be used easily in quite other contexts. ${ }^{5}$

Back at c. 1300/1290 BC, brt occurs repeatedly in a particular type of context in a decree of Sethos I. ${ }^{6}$ Here, brt is a socio-economic term: '(hire) contract', to be compared with a further example under Merenptah c. $1210 \mathrm{BC}$, ${ }^{7}$ of bryt, '(women on) hire contract'. This use goes back to c. $1400 \mathrm{BC}$ at Qatna in Syria. ${ }^{8}$ Here, the headings of two tablets listing personnel and supplies issued employ the phrase TAR beriti-'making ("cutting") an agreement, again a contract, it would appear.

But religious usage also occurs. At Ugarit (thirteenth century BC), a Hurrian hymn to the Semitic god El addresses him (inter alia) as 'El.brt, 'El.dn. 'El.dn was immediately recognised as 'El of Judgement'; and it was not long before 'El.brt was recognised in turn as ' $\mathrm{El}$ of the Covenant', and hence to be compared directly with the 'El-berit of Judges 9:46, and with $B a$ 'al-berit of Judges 8:33, 9:4, in narratives whose subject-matter would belong to the twelfth/eleventh centuries $B C$. What is more, this 'El-berit of Ugarit occurs in the context of deities who act as witnesses in fourteenth/thirteenth century treaties. ${ }^{9}$

In short, this group of first-hand data exhibits the robust and well-established use of berit in all spheres (religion/theology; social contexts; political realm) already, during the period $c .1400-1170 \mathrm{BC}$, the end-part of this period

\footnotetext{
${ }^{4}$ See Kitchen, UF 11 (1979) 453-4 with references.

${ }^{5}$ That the Libyans actually used the term themselves is altogether a less likely proposition, though not impossible. So far we possess no early Libyan texts.

6 Kitchen, op. cit. 454-7.

7 Ibid. 457-8.

8 Ibid. 459 and references.

9 References, ibid. 458.
} 
overlapping with the presence of Israel itself in Canaan from before 1207 BC onwards. ${ }^{10}$ This inescapable situation constitutes clear disproof that berrt must wait until the eighth/seventh centuries BC to be used thus in West Semitic, Hebrew included. On this point, the WellhausenPerlitt/Kutsch-Nicholson position cannot now be sustained. The full use of the term and concept runs from the later second millennium $\mathrm{BC}$ onwards. On the origin of the term berit, there is every reason to stay with the interpretation as 'bond', both on the distribution of terms across the relevant languages ( $r i k s u$, msm(d)t, beritu, all 'bond', and used in hendiadys constructions with terms for 'oath'). ${ }^{11}$ Furthermore, the religious concept of covenant (linking man and deity) goes far back beyond even $1400 \mathrm{BC}$ into the third millennium $\mathrm{BC}$, being attested between king Uru'inimga ('Urukagina') of Lagash and his deity Ningirsu. ${ }^{12}$ So, a proper perspective goes well beyond any suggestion of limiting the impact of 'covenant' to the period from the seventh century BC onwards.

But what of the question of treaty and covenant, so confidently pronounced a 'dead-end' by Nicholson (p. vi; cf p. 81)? Here, matters are also unsatisfactory.

As noted above, Nicholson does not attempt to interact with the evidence of the treaties themselves, but deals with them only at second-hand through the inadequate presentations found in the pages of McCarthy and Weinfeld in particular, plus Mendenhall. Moreover, both he and they

10 The twelfth-century Egyptian mentions of berit were available in brief form in 1912: M. Burchardt, Die altkanaanäischen Fremdworte und Eigennamen im Aegyptischen I-II (Leipzig, Hinrichs 1909/10) in II 20 no. 365; cf. earlier, J. H. Bondi, Die dem hebräisch-phönizischen Sprachzweige angehörenden Lehnworte in hieroglyphischen und hieratischen Texten (Leipzig 1886) 41, XXXI.

11 Kitchen, op.cit. (n. 4) 459-63. The Arslan Tash amulets should be eliminated from the evidence, as they are modern forgeries: see J. Teixidor and P. Amiet, Aula Orientalis 1 (1983), 105-9, and esp. J. Teixidor, Bulletin de l'épigraphie sémitique (1964-80) (Paris, Geuthner 1986) 471-2.

12 Kitchen, op.cit. (n.4) 462, n.77; cf. now, J. S. Cooper, Sumerian and Akkadian Royal Inscriptions I (New Haven, Conn., American Oriental Society 1986) 70 (king's name) 73 top ('solemnly promised'; 'covenant' in prior translations). 
make the mistake of concentrating exclusively on the treaties, for comparison with covenant. This is why, in agreement with Nicholson, this limited field of comparison is unsatisfactory. But neither he nor they appear to realize that what is missing is the corpora of law. For some eighty years the many comparisons that exist between Hammurabi's laws and the pentateuchal laws have been widely known; to those may be added the law-collections of Ur-Nammu, Lipit-Ishtar and from Eshnunna, plus others. At the heart of the Sinai covenant stands law, ostensibly to guide conduct of a people's life; and not just a treaty on the religious plane. Nevertheless treaty is an unavoidable component. The reason for all this is that the covenant in Exodus-Leviticus, Deuteronomy and Joshua is a confluence of law and treaty; ${ }^{13}$ law, treaty and covenant form a conceptual tryptych. How does this work out in practice?

What features do the Sinai covenant and its renewals exhibit in the existing Old Testament text (the only objective source we have)? Here, there is space only to give the bare essentials. But in I (Ex.-Lev.), II (Deut.), and III (Jos. 24), the following features clearly appear.

1. Title/preamble ${ }^{14}$

2. Historical Prologue ${ }^{15}$

3a. Basic commands 3b Detailed laws ${ }^{16}$

4a. Deposit of text

4b. Public reading (sometimes) ${ }^{17}$

5. Witnesses ${ }^{18}$

6a. Blessings for obedience (brief) ${ }^{19}$

13 A point already made in Kitchen, The Bible in its World (Exeter, Paternoster Press 1977) 183 top-not discussed by Nicholson.

14 I: Ex. 20:1; II: Dt. 1:1-5; III: Jos. 24:2 (middle).

15 I: Ex. 20:2; II: Dt. 1:6-3:29; III: Jos. 24:2b-13.

16 I: Ex. 20:3-17 (basic); Ex. 20:22-6; 21-3; 25-31 (laws); Lev. 1-25 passim (ritual and service). II: Dt. 4; 5-11; 12-26. III: Jos. 24:14-15.

17 I: Ex. 25:16 (plus Dt. 10:2, 5, retrospect), deposit only mentioned. II: Dt. 31:246 (deposit); 31:10-13 (regular reading). III: cf. Jos. 24:26 (document).

18 I: Ex. 24:4 (twelve stelae; cf. those at Gilgal, Jos. 4:3-9, and Shechem, 24:27).

II: Dt. 31:19-22, 30 (ch. 32), song; 31:26 (laws document). III: Jos. 24:22 (people),

27 (stela).

19 I: Lev. 26:3-13 (10 verses). II: Dt. 28: 1-14 (14 verses). III: [not given]. 
6b. Curses for disobedience (extensive) ${ }^{20}$

7. Epilogue 21

If we examine the texts of the known law-'codes' and of all the available treaties, ${ }^{22}$ a very clear picture emerges. ${ }^{23}$

Of the seven law-codes, four are of the late third and early second millennium; one is simply an 'extract' text, but three show a full literary form, as follows:

1. Title/preamble

2. (Religious) prologue

3. The Laws

4. Epilogue

5a. Blessings (brief)

5b. Curses (extensive)

The three later codes (Hittite and Middle-Assyrian, late second millennium BC; Neo-Babylonian, first millennium $B C)$ have only the laws, no setting.

In the series of over forty treaties (at least six existing in bilingual versions), four distinct main periods can be distinguished. ${ }^{24}$

I. Early (third millennium BC), in both 'simple' form (Ebla/Abarsal) ${ }^{25}$ and complex in the East (Akkad/Elam; Lagash/Umma). ${ }^{26}$

II. Intermediate (early second millennium BC), which vary from nuclear simplicity in Mesopotamia, ${ }^{27}$ via a standard

20 I: Lev. 26: 14-41a (27 verses). II: Dt. 28: 15-68 (53 verses). III: Jos. 24:19-20.

21 II: Dt. 29:2-30:20.

22 A full survey of this material by the present writer awaits publication.

23 Most of the evidence from c.2300 BC to $650 \mathrm{BC}$ was presented analytically in my Bible in its World, 1977 79ff.

24 Not noted by Nicholson or his three sources, Mendenhall, McCarthy, Weinfeld; cf. Bible in its World 79-81.

25 In Bible in its World 80, correct to 'between Ebla and Abarsal' (omitting 'Tudiya of Assyria'). For that document, see E. Sollberger, Studi Eblaiti 3 (1980) 129-55, fig. 27a-8; see also W. G. Lambert in L. Cagni (ed.), Ebla 1975-1985 (Naples 1987) 353-64.

26 Both of these show the Sumerian usage of repeating certain elements with each segment of the main text (in this case stipulations).

27 So the commercial treaty between Sumu-numhim and Ammi-dashur (Title/Stipulations/Colophon); cf. S. Greengus, Old Babylonian Tablets from Ishchali and Vicinity (Leiden, Nederlands hist.-arch. Instituut 1979) 74-7. 
form in N. Syria and Hatti, leading on to a fuller form in Hatti $^{28}$ by c. 1400 BC. ${ }^{29}$

III. Middle (late second millennium BC), during fourteenth-thirteenth centuries $\mathrm{BC}$-more than twenty treaties from Hittite sources. If one sets out and analyses the twentyseven available documents (adding in bilingual versions), but omits one 'extract' document (Kaskeans no. 138) ${ }^{30}$ and three fragmentary pieces (one version each, of Suppiluliuma I with Sunassura and KURtiwaza respectively, and of Mursil II with Duppi-Tesup), then the data from the twenty-three reasonably preserved documents are remarkably consistent in both content and arrangement, thus:

1. All nineteen with beginning preserved have a title/preamble; 5 others are broken.

2. Historical prologues (varying length) occur in twentytwo of the twenty-four 'good' documents (broken away in two cases), and in one of the four fragment-texts.

3. Stipulations survive in all twenty-four 'good' texts; and in two of the fragments.

4. Deposit of text is explicit in four texts, and public reading in four texts; it is omitted in six complete texts. However, ten 'good' and two fragment texts are broken away at this section, and another text (Hattusil III-Benteshina) was left incomplete after the stipulations. So, the original total for this feature was originally up to sixteen/seventeen texts.

5. Witnesses are present in twenty of the documents; just twice, they occur at an earlier point in the text (Hayasa, and Kaska peoples [138]).

28 N. Syria: Title/Stipulations/Curses (Niqmepa, Idrimi, at Alalakh); Hatti (Zidantas, Paddatišu; ends lost).

29 Arnuwandas I: Title/Witnesses/Stipulations/Oath/Curses [and blessings??].

30 Treaties 'nos. 138, 139' = Kaskean/Hittite treaties in E. Laroche, Catalogue des textes hittites (Paris, Klincksieck 21971) 20 no. 138 (= E. von Schuler, Die Kaskäer [Berlin, W. de Gruyter 1965] 117f. 139) and no. 139 (= von Schuler, op. cit., 109ff.). Hayasa treaty in Laroche, op. cit. 9 no. 42 (= J. Friedrich, Hethitische Staatsverträge II [Leipzig, Hinrichs 1930] 1106-36). Now included in the reckoning given here is the treaty of Tudkhia IV with Kurunta on a splendid bronze tablet just published by $\mathrm{H}$. Otten, Die Bronzetafel aus Bogazköy, ein Staatsvertrag Tuthalijas IV (Studien zu den Bogazköy-Texten, Beiheft 1; Wiesbaden, Harrassowitz 1988). 
$6 a / b$. Curses then blessings, always in this order, always together, usually of similar extent, are preserved in fifteen of the 'good' texts; ten more are lost. Of the basic fifteen, all have this feature at the end (one has an additional set early in the text); two have supplementary data after this feature.

Thus, it is in order to point out the considerable consistency in order and content in this large group of documents, especially when the scope and placement of lacunae in tablets is properly accounted for. This salient fact of major consistency is not clearly presented in McCarthy or Weinfeld, and consequently it is not picked up by Nicholson.

IV. Late (first millennium BC)-here, we have one basic set of contents, much reduced in scope: title and witnesses, followed (in the West) by curses and stipulations or (in the East) by stipulations then curses; one eastern document also reverts to a 'complex' pattern of third millennium inspiration.

Series I, II and IV have nothing in common with the Laws and III except the core-elements of title, stipulations, witnesses and curses. But the Laws, III and Sinai covenant ( 3 variants) show a remarkable comparison when properly exhibited together, thus:

LAW

1. Title/Preamble

2. Prologue (religious)

3. Laws

4. Epilogue

\section{SINAI COVENANT}

1. Title/preamble

2 Historical prologue

3. Laws, regulations

4a/b.Deposit;

Reading

5. Witnesses

5a Blessings (few)

5b. Curses (many) 6a Blessings (few)

6b. Curses (many)

7. Epilogue
TREATIES III

1. Title/preamble.

2 Historical prologue

3. Stipulations

4a/b.Deposit;

Reading

5. Witnesses

6b Curses

6a. Blessings

From this table, we can see directly the 'confluence' mentioned above. Covenant has Title/preamble in common with Law, Treaty, and other genres. Covenant shares Prologue with both Law and Treaty, having religious overtones with the former, and mainly historical content with the latter. 
Covenant has some provision for Deposit and Public readingas have the Treaties; Law has stela in temple for public to consult [Hammurabi]. Covenant has Witnesses, in common with Treaty. (Not in Laws.) Covenant has few Blessings and then many Curses-just like Law; Treaties share this double feature, but elements reversed and more even-handed. Covenant has passages of Epilogue, as does Law. Covenant has laws and regulations that largely go with Law; but in part are the equivalent of Treaty stipulations (despite Nicholson).

To sum up. The Sinai Covenant has the closest expectable links with both third/early second millennium Laws and the late second millennium Treaties, the links varying directly with function. Of distinctive features, Prologue, Laws, Epilogue, and few Blessings/many Curses all go with Law; the historical component of Prologue, Deposit/Reading, Witnesses and a Curses/Blessings topos are all held in common with Treaty type III, and not with I, II, IV other than basic Witnesses/Curses. Thus, the form and content of the Sinai Covenant is beyond serious doubt a clear confluence of the much older Law tradition with the late-secondmillennium treaty format-and the covenant represents a fresh and distinctive formulation, intelligently using those two components (it is not just a crude pastiche of either or both).

In the remaining two sections certain contentious details need consideration (VI) before drawing conclusions (VII).

\section{VI}

\section{Contentious Details}

(i) The fact of clear distinctions in content and format between treaties of different periods. This is glossed-over and denied by McCarthy ${ }^{31}$ and Weinfeld. ${ }^{32}$ But, as an examination and analysis of all the available data makes clear, there is no way of legitimate escape from the clear correspondences of latesecond-millennium treaties plus the early law-codes with the

31 Treaty and Covenant (Rome, Biblical Institute Press 1978) 122; quoted by Nicholson, p. 60 and used by him without verifying the facts against the treaties themselves.

32 M. Weinfeld, Deuteronomy and the Deuteronomic Schools (Oxford, OUP 1972) 59-61, also cited in Bible in its World 147, n. 35. 
Sinai covenant, or from the clear differences between these linked corpora and the first-millennium treaties. The phenomenon of few blessings/many curses goes with early law, not with Assyrian treaties [no blessings]. In content, there are direct comparisons between curses in Neo-Assyrian treaties and Deuteronomy 28 (as Frankena saw)-but, as Weinfeld himself pointed out long ago, ${ }^{33}$ this common tradition itself reaches back over a millennium into Old-Babylonian (i.e., Patriarchal) times! It does not indicate direct dependence of Deuteronomy 28 on the Assyrian documents as Frankena mistakenly thought.

(ii) Basically, the three reports of the Sinai covenant and renewal show not only analogous content with secondmillennium Law and Treaty, but also to a remarkable extent the same order of features. This is entirely so in Joshua 24, and almost entirely so in Exodus-Leviticus and Deuteronomy. Even the visible variations can be directly paralleled. Thus, Deuteronomy follows the common sequence throughout, except that Blessings plus Curses precede the Epilogue (chapter 29), Deposit/reading and witnesses, instead of following them. And in Exodus-Leviticus, the witness and deposit are placed relatively early in the proceedings, among the groups of laws (Exodus 24:4; 25:16). Such variations have their reasons, and find parallels in the second-millennium documents. Thus, for witnesses and curses/blessings placed early in a treaty, between two groups of stipulations, we have the treaty of Suppiluliuma I and the people of Hayasa; and for stipulations (plus oath and ceremony) added after curses/blessings, we have a treaty (No.139) with the Kaska people (cf. Lev. 27 after 26). Witnesses are placed early also in Kaska No. 139. Significantly, these variations in common with Exodus-Leviticus and Deuteronomy occur in treaties made with peoples, tribes, not kingdoms-just as the covenant of $\mathrm{YHWH}$ is with the Israelites, not with a human ruler of a territorial vassal-state. In wider terms, it should be no surprise if some variations do occur. (1) We have here a covenant, not a treaty, so differences may be expected. (2) A new category ('covenant') a confluence of two other related ones (law, treaty) may follow its own path

33 In Biblica 46 (1965) 422, 423. 
in how elements from both may be combined. (3) ExodusLeviticus, Deuteronomy and Joshua 24 are not themselves formal treaty (or even covenant) documents, like the cuneiform records. They are the retrospective narrative reports of the covenant and renewals actually being enacted. And the sequence of events is not always the sequence of formal record, in antiquity. ${ }^{34}$ And narrative 'frame' can be found also with the treaties, as with Ramesses II/Hattusil III (Egyptian version), and the Talmi-sharruma treaty.

(iii) Nicholson criticizes Hillers and others for arguing the unity of Deuteronomy 28 on the basis of treaty curse-lists, alleging that such scholars have made the treaty-analogy "the controlling factor" (pp. 74, 75). Precisely. The law-codes and treaties in our possession are first-hand, original documents drawn up (in each case) at a particular point in time-they are not the product of 'layers' of tradition brought together across centuries, even though they may draw upon pre-existing cursetraditions and formulae. It is the literary procedures of these first-hand documents therefore, that should serve to control our treatment of the analogous passages in Deuteronomy 28; while the common literary-critical approaches should be subjected to external control and verification-not the other way round. Hence Nicholson's criticism misses the point.

(iv) Of treaty-terminology, real or supposed, various terms are listed by Nicholson (pp. 61-64), then their adduction criticised by him (pp. 78-81). In warm agreement with Nicholson, it is well-justified to stress that terms like 'father', 'brother', 'son', 'love', 'know/recognise', etc., are-most of the time-simply part and parcel of Israelite daily and social life, rather then reflections of covenant (or treaty). However, in making this point, he overstates his case. For, as Weinfeld pointed out ${ }^{35}$ it is clear that the basic terms are used in treaty/covenant context in hendiadys constructions; and two terms can be picked out of

34 At random, cf. the different sequence of procedure for the Festival of Min, presented by the reliefs and by the programme-text; G. A. Gaballa, Narrative in Egyptian Art (Mainz, Ph von Zabern 1976) 98, 154, n. 48, contra Gauthier.

35 'Covenant Terminology in the Ancient Near East and its Influence on the West', JAOS 93 (1973) 190-9. 
the two halves of a double hendiadys to encompass the whole. Weinfeld also carefully separates out usage of such terms that is not covenantal. So, the matter of terminology needs careful consideration. A particular case may here be noted. In Deuteronomy, up to chapter 28 , b̌rit is used alone for 'covenant'. But after the oath-element of blessings and curses (ch. 28), the hendiadys-form berit-we-ala, 'bond and oath' (Deuteronomy 29: 11,13 [Heb. 12,14, EV]). This particular subtlety is shared, so far, only with the treaties of the fourteenth/thirteenth centuries BC, in which riksu, 'bond', is followed after the oathelement, by riksu u mamitu, 'bond and oath', as already noted by Korosec. ${ }^{36}$ Regarding such terms as segulla, the significant point is that the external evidence for this word and root in Ugaritic and Akkadian proves (i) they are not just 'Deuteronomic' and (ii) they are not 'late', e.g. seventh century $\mathrm{BC}$, but go back into the second millennium $\mathrm{BC}$.

(v) The issue of a title/preamble and prologue in Exodus 20. Contrary to McCarthy, and Nicholson, the text does contain a brief form of each feature, exactly as in fourteenth/thirteenthcentury examples. As for preamble, Exodus 20:1:

'Then God spoke all these words, saying:-' is the narrative equivalent of the short preamble found (e.g.) in the treaty of Mursil II with Niqmepa of Ugarit, thus:

'Thus speaks the Sun, Mursilis the Great King, King of Hatti-land:-'

And for brief prologue, Exodus 20:2:

I am YHWH your God,

who (has) brought you out of the land of Egypt, out of the house of bondage.'

Compare Mursil II/Niqmepa:

'As for you, Niqmepa,

as I have [reconciled] you and your peers,

and sought to ensure your installation as king,

on your father's throne,

so you and my people are (now) my subjects.'

36 See V. Korosec, Hethitische Staatsverträge (Leipzig, Weicher 1931); pointed out again, Kitchen, UF 11 (1979) 463, n. 80. 
(vi) The lack of blessings and curses in Exodus stems from modern failure to note their presence at the end of Leviticus (ch. 26). It should not be overlooked that the whole of Exodus 19:1 to Leviticus 27:34 is explicitly set as one series of acts, speeches and events at and around Mount Sinai; this unity of time and place is over-arched by the covenant, even if not all in ExodusLeviticus is covenantal.

(vii) Deuteronomy, we are told (Nicholson, p. 71) is 'not treatylike in its manner of presentation; rather, it is a valedictory speech of Moses, an extended oration in homiletic style.' Exactly-up to a point. Examination of the fourteenth /thirteenth-century treaties, reveals that they, too, are cast as speeches. Moses' real valediction begins not in Deuteronomy 1, but is contained in Deuteronomy 31:1-8. Nicholson's denial of the role of preamble and historical prologue to Deuteronomy 13 (despite Weinfeld) is without merit. Deuteronomy 1:1-5 (not v. 6) is a preamble in a syntactically elaborate style like that of Hammurabi of Babylon for his laws half a millennium earlier; $1: 5$ ends with '...saying...', as a preamble ought to. Deuteronomy 1:6-3:29 is a particularly clear example of a historical narrative in prologue-form: it emphasises the interrelationships of $\mathrm{YHWH}$, Israel and Moses in the events from Horeb to Moab. As an introduction to the renewal of the covenant, it could not be more fitting; as introduction to the entire supposed length of the so-called 'Deuteronomic history', it is an irrelevance.

\section{VII \\ Conclusions}

The works of McCarthy and Weinfeld, on which Nicholson draws, obscure the clear differences between the fourteenth/thirteenth-century treaties and first-millennium examples. The former treaties have, while the latter do not have historical prologues, ${ }^{37}$ blessings to match curses, ${ }^{38}$ and

37 The supposed trace in the treaty of Assurbanipal and Qedar is not a prologue. After the now lost title and witnesses (of the latter a trace subsists), just one historical allusion occurs, used to clarify and justify Assurbanipal's dispositions that follow. For this text see A. K. Grayson, JCS 39 (1987) 147-50 no. 6. All the 
deposit/reading clauses. The Sinai covenant is clearly related to the format of the early law-codes and to the fourteenth/thirteenth-century treaties, drawing on both to produce its own formulation; c. $1200 \mathrm{BC}$ is the bottom dateline for this to happen. As Israel were already in Canaan before 1207 BC (Year 5 of Merenptah, the 'Israel stela'), they overlap with the external data on brt at that general period. That Israel could somehow be hermetically excluded from knowing about berft until the eighth/seventh centuries BC (about half a millennium later!) under these circumstances is inconceivable.

Secondly, criticisms of correlations merely between treaty and covenant miss the point. It is law and treaty that are together the seed-bed of covenant. The Sinai covenant drew upon the collective experience of over half a millennium of law, and (at c. $1250 \mathrm{BC}$ ) on a century and a half of treaty. These usages extended across the entire biblical world, at a time of great cosmopolitanism in culture. A Moses at the Egyptian court would have found it well-populated by fellow West-Semites, among many others (Hurrians and the rest).

Thirdly, the Wellhausenian view (espoused by Nicholson) that Israel had some kind of 'natural bond' religion until the eighth/seventh century $B C$ is an illusion, having arisen through Wellhausen's ignorance of what ancient religion was really like. No one had such a solely joyful, non-guilt 'natural bond' religion in the Ancient Near East at any time for which we have proper documentation. One might cite the Mesopotamian rituals obsessed with placating the gods, and anxiously confessing sins unknown, which go well beyond the level of the biblical 'priestly' traditions that Wellhausen so openly despised. 'Prophetic' denunciation of empty formality in cult-practice did not have to await the eighth century to be proclaimed (or even just till Samuel). With 1 Samuel 15:22, 'to obey is better than sacrifice, and to pay heed more than the fat of rams', one may compare 1,000 years earlier 'More acceptable

Neo-Assyrian treaties are now available in S. Parpola and K. Watannbe (edd.), Neo-Assyrian Treaties and Loyalty Oaths (State Archives of Assyria II; Helsinki 1988).

38 The only blessings in any first-millennium treaty occur in the Epilogue to Sfire I-and these relate exclusively to those who respect the monument itself, without any reference to the treaty. Hence, they are irrelevant. 
is the character of the upright/faithful, than the (sacrificial) bull of the wrongdoer', as the Instruction for Merikare puts it. ${ }^{39}$ As the matter of covenant makes clear, there is no factual, independent basis for Wellhausen's basic scheme of Israelite religious development.

Further, in a paper delivered in Jerusalem on the centenary of Wellhausen's Prolegomena Weinfeld drew attention to the nature of the work: (1) the Prolegomena was not a piece of impartial scholarship, but rested on deep anti-Jewish prejudice which regarded the Law as a dead fossil at the heart of Judaism; ${ }^{40}$ (2) its author was singularly ill-informed on the inner nature of Judaism; (3) his late dating of the law (especially the ' $\mathrm{P}$ ' element) rested on this prejudiced view, not upon any compelling facts; (4) five essential bases of Wellhausen's position [place of worship; evolution of sacrifice; festivals; priests and Levites; 'endowment of clergy'] are contradicted by independent biblical evidence (as shown by Kaufmann, Hurwitz, etc.), and totally by the independent firsthand data from the biblical Near East. This evaluation is noteworthy coming as it does from a scholar with no 'fundamentalist' axe-conservative or liberal, Christian or Jewish - to grind. ${ }^{41}$ Very much more factual and germane data is abundantly available to support Weinfeld's position. From Syria alone, now we have not just the isolated source, but a succession of important sites rich in documentation: Ebla (third millennium), Mari (third-early second millennium), Qatna (mid-second millennium), Ugarit (fourteenth/thirteenth centuries), and now Emar (thirteenth century, as yet little known to Old Testament scholars).

It is regrettable that Nicholson's book-which in this regard may exemplify the present trend in Old Testament scholarship-attempts to turn the clock back 100 years by

39 Accessible, Wilson, in Pritchard, ANET 417b (:125/130); edition, W. Helck, Die Lehre für König Merikare (Wiesbaden, Harrassowitz 1977) 80-1.

40 Ironically, it is now Wellhausen's work and views that are a dead fossil which threaten to impede progress in Old Testament study.

41 Moshe Weinfeld, Report No. 14/79: Getting at the Roots of Wellhausen's Understanding of the Law of Israel, on the 100th Anniversary of the Prolegomena (Jerusalem, the Hebrew University: Institute for Advanced Studies 1979); 47pp. 
ignoring the Ancient Near Eastern evidence so germane to the issue. As we prepare to enter our third millenium the future course of the discussion ${ }^{42}$ of covenant, law and treaty in the Old Testament would be altered for the better by moving the focus back, not to the nineteenth century $A D$ but to the second millenium $B C$ where a much more secure base exists for the evaluation of these biblical texts.

42 A full-scale return to Wellhausen's essential position inevitably means jettisoning a vast amount of painstaking work-the relevant works (cf. I, II above) by Kittel, Steuernagel, Procksch, Gressmann (1913), Mowinckel, Hempel, Weiser, Galling, Eichrodt, Gunkel, Porteous, Robinson, Rowley, Wright and Noth (ch. 2); a good part of Mendenhall, McCarthy and Weinfeld on covenant and Near East, and much by Moran, Malamat, Fensham, Beyerlin, Hillers, Huffmon, among others (ch. 3), not excluding Max Weber. From a scholarly point of view there would have been no choice in the matter if there were discovered a body of new evidence, such as the excavation of well-dated early manuscripts which proved (for example) that the Deuteronomic style was an innovation of the late seventh century $B C$. But this is not the case. 